\title{
Genetic divergence in mitochondrial DNA of Anopheles nuneztovari (Diptera: Culicidae) from Brazil and Colombia
}

\author{
Vera Margarete Scarpassa ${ }^{1}$, Silvia Geurgas ${ }^{2}$, Ana Maria L. Azeredo-Espin ${ }^{2}$ and Wanderli Pedro Tadei ${ }^{1}$
}

\begin{abstract}
In the present study, we have examined the variability in Anopheles nuneztovari mitochondrial DNA of three populations from the Brazilian Amazon and one from western Colombia (Sitronela), using four restriction endonucleases (BclI, ClaI, HindIII, SstI). The haplotype diversity $(h)$ was slightly elevated in all populations $(0.5000$ to 0.6765$)$, whereas the nucleotide diversity $(\pi)$ was lower in the Sitronela population (0.0029) and higher in populations from the Brazilian Amazon (0.0056 to 0.0098). The degree of sequence divergence $(\delta)$ estimated within the Brazilian Amazon and that in Sitronela (0.0329 to 0.0371) suggests that these geographic populations of $A$. nuneztovari may eventually constitute separate species. The low sequence divergence values among the three Brazilian Amazon populations ( 0.0012 to 0.0031$)$ indicate that these populations are genetically similar. These results are consistent with those recently reported for allozymes of these same populations.
\end{abstract}

\section{INTRODUCTION}

Speciation in the genus Anopheles often involves little morphological change accompanied by considerable genetic differences (Coluzzi, 1988). Up until the end of the 50s, only two species complexes, the Anopheles maculipennis complex from Europe and the A. gambiae complex from Africa, were known. Currently, 12 sibling species complexes are recognized and the evidence suggests that the most important vectors in human malaria are members of these complexes (Collins and Paskewitz, 1996). The separation and identification of the species has been done basically through experimental crossing (when possible), polytene chromosome analysis, allozyme comparisons and DNA analysis (Narang and Seawright, 1990; Mitchell et al., 1992).

Mitochondrial DNA (mtDNA) has been used extensively in population studies of many organisms, because of its rapid evolution, lack of recombination and maternal inheritance (reviewed in Roderick, 1996). The high rate of substitution in mtDNA makes it a powerful tool to address evolutionary questions, especially for those groups which include recently evolved taxa, such as the anopheline mosquitoes. The restriction patterns of mtDNA were used to distinguish the isomorphic species A, B, C and D of the A. dirus complex (Yasothornsrikul et al., 1988), as well as species of the A. quadrimaculatus (Mitchell et al., 1992) and A. albitarsis (Narang et al., 1993) complexes. At the intraspecific level, mtDNA studies have enabled the estimation of intra- and interpopulational variability, sequence divergence, and historical and phylogeographic patterns, as well as the degree of gene flow in A. aquasalis
(Conn et al., 1993a), A. quadrimaculatus, A species (Perera et al., 1995), A. darlingi (Freitas-Sibajev et al., 1995; Conn et al., 1999), A. gambiae and A. arabiensis (Lehmann et al., 1997; Besansky et al., 1997), A. rangeli and A. trinkae (Conn et al., 1997) and A. nuneztovari (Conn et al., 1998).

Anopheles (Nyssorhynchus) nuneztovari Gabaldón is a Neotropical anopheline found in northern South America and eastern Panama (Faran, 1980). This species is an important vector of human malaria in several localities in Colombia and in Venezuela (Gabaldón, 1981; RubioPalis and Curtis, 1992). However, the vector competence of A. nuneztovari in the Brazilian Amazon is still unresolved (Deane, 1986), in spite of being found containing the malaria parasites Plasmodium vivax and P. falciparum (Arruda et al., 1986; Tadei et al., 1993).

Elliott (1972) suggested that A. nuneztovari consists of two allopatric forms or ecotypes. Populations from northern Colombia and western Venezuela are predominantly anthropophilic and endophagic, with peak activity around midnight, and are considered malaria vectors. Populations from other localities, including Brazil, show accentuated zoophily and exophagy, bite in the early evening and are not considered malaria vectors. Studies of polytene chromosomes in A. nuneztovari have identified three cytotypes (Kitzmiller et al., 1973; Conn, 1990; Conn et al., 1993b). Cytotypes B and C differ from cytotype $\mathrm{A}$ by a fixed inversion in the $\mathrm{X}$ chromosome, by the frequencies of inversions in autosomic chromosomes and by the presence of a chromocenter. Cytotype A occurs throughout the Amazon Basin, cytotype B is observed in populations from western Venezuela (eastern Andes) and 
cytotype $\mathrm{C}$ is found in Colombia and western Venezuela (western Andes). Comparative isozyme studies have shown low differentiation between populations from Brokopondo (Suriname) and Barinas (Venezuela) (Steiner et al., 1980), as well as between populations from both sides of the Andes, in Venezuela (B and C cytotypes) (Fritz et al., 1995). Other investigations have suggested that populations from the Brazilian Amazon are genetically similar. Higher genetic divergence was found between populations from the Brazilian Amazon and Colombia, resulting in three groups: one in the Brazilian Amazon and two in Colombia (Scarpassa et al., 1999). Sequence analysis of the ITS2 region of ribosomal DNA (rDNA) from nine populations revealed that samples from Colombia and Venezuela had identical sequences. These populations differ from those at other localities (including Brazil) by three insertion/ deletion events and one transversion (Fritz et al., 1994). At least three groups were identified by these authors: 1) Bolivia, Colombia and Venezuela, 2) northern Brazil and Suriname and 3) central and eastern Brazil. Comparison of the mtDNA from 12 populations also showed three distinctive lineages, one in Colombia/Venezuela and two in the Amazon Basin (Conn et al., 1998). Analysis of the male genitalia indicates that cytotype B males (Venezuela) are more differentiated than in the other two cytotypes (Hribar, 1994). Variations in egg ultrastructure have also been noted between populations from Venezuela and the Amazon Basin. In the Brazilian Amazon, populations from the west did not cluster with collections from the north, central region and east (Linley et al., 1996).

Since differences in the vectorial capacity of a species can correlate with genetic divergence (EstradaFranco et al., 1993), the use of genetic markers is important for studying geographic populations of $A$. nuneztovari. In this study, we describe the mtDNA variation of three populations from the Brazilian Amazon (cytotype A) and one from western Colombia (cytotype C). We estimated the intrapopulation diversity and the nucleotide sequence divergence, and correlated these results (mitochondrial genome) with isozyme data (nuclear genome) recently obtained for these same samples (Scarpassa et al., 1996, 1999).

\section{MATERIAL AND METHODS}

Populations of $A$. nuneztovari were obtained from three sites in the Brazilian Amazon (Puraquequara (PUR), Amazonas State; Tucuruí (TUC), Pará State, and Nova Mazagão (NOMA), Amapá State), and one site in Colombia (Sitronela (SIT), Valle State) (Figure 1). Mosquitoes (females) were collected between 18:00 and 21:00 $\mathrm{h}$ while feeding on cattle, resting on stable walls (PUR and

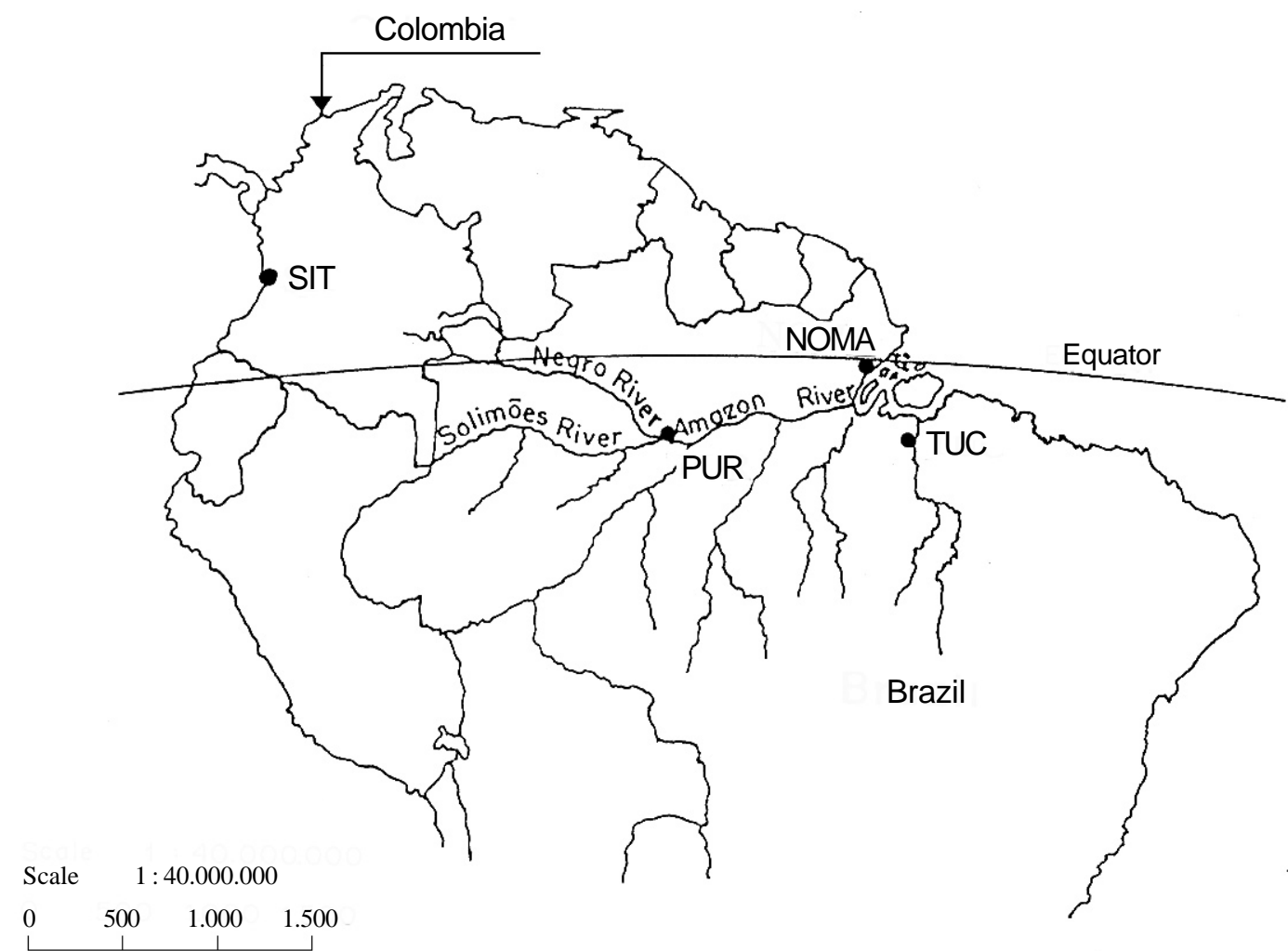

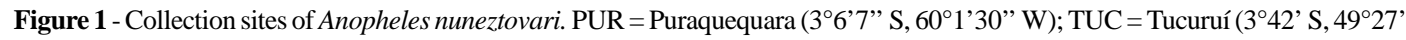
W); NOMA = Nova Mazagão $\left(0^{\circ} 7^{\prime}\right.$ S, $\left.51^{\circ} 17^{\prime} \mathrm{W}\right)$; SIT = Sitronela $\left(3^{\circ} 49^{\prime} \mathrm{N}, 77^{\circ} 4^{\prime} \mathrm{W}\right)$. 
NOMA), or using human bait (TUC and SIT). After being caught, blood-fed mosquitoes were individually isolated in plastic cups for egg laying. Following oviposition and eclosion, the offspring were reared until the 4 th instar larval, pupal and adult stages, when they were frozen at $-70^{\circ} \mathrm{C}$, until analyzed. The offspring from isofemale broods were used for isozyme and mtDNA analyses. Morphological identification of the egg and adult stages was done according to Cova-Garcia (1961) and Gorham et al. (1967); when necessary the 4th instar larvae and male genitalia were identified.

Total nucleic acids were isolated from 4th instar larvae $\left(\mathrm{F}_{1}\right)$ using the methods described by Infante-Vargas and Azeredo-Espin (1995), with adaptations. Individual larvae were homogenized in 1.5-ml Eppendorf tubes, containing $100 \mu$ l of homogenization buffer $(10 \mathrm{mM}$ Tris, $60 \mathrm{mM} \mathrm{NaCl}$, $300 \mathrm{mM}$ sucrose, $10 \mathrm{mM}$ EDTA). After homogenization, $100 \mu \mathrm{l}$ of lysis buffer ( $300 \mathrm{mM}$ Tris, $40 \mathrm{mM}$ SDS, $20 \mathrm{mM}$ EDTA) containing 2\% DEPC was added, followed by incubation on ice for $15 \mathrm{~min}$. Two hundred microliters of buffersaturated phenol (0.5 M Tris, $\mathrm{pH}$ 8.0) was added and the mixture then centrifuged at $5000 \mathrm{~g}$ for $5 \mathrm{~min}$. The supernatant was transferred to a new tube and phenol: chloroform:isoamylic alcohol (proportions: 25:24:1, v/v) was added and centrifuged at $5000 \mathrm{~g}$. The supernatant was transferred to a new tube and chloroform:isoamylic alcohol (proportions: 24:1, v/v) was added and again centrifuged. The final supernatant was precipitated in ethanol at $-70^{\circ} \mathrm{C}$ for $30 \mathrm{~min}$, and centrifuged at $12000 \mathrm{~g}$ for $30 \mathrm{~min}$ to obtain the pellet of the DNA. The pellet was dried at room temperature, resuspended in $50 \mu \mathrm{l}$ of $1 \mathrm{X}$ TE buffer $(10$ $\mathrm{mM}$ Tris- $\mathrm{HCl}, 1 \mathrm{mM}$ EDTA, $\mathrm{pH} 8.0$ ), and stored at $-20^{\circ} \mathrm{C}$ until analyzed.

Total DNA of individual A. nuneztovari larvae was digested with five restriction endonucleases: $B c l \mathrm{I}$ (T/ GATCA), ClaI (AT/CGAT), EcoRI (G/AATTC), HindIII (A/ AGCTT), and SstI (GAGCT/C). The digestion and incubation conditions were based on the manufacturer's (GIBCO,
BRL) specifications. The DNA fragments were separated in $1 \%$ agarose gels, and visualized by ethidium bromide staining $(0.1 \mathrm{~g} / \mathrm{ml})$. The sizes of the restriction fragments were estimated using DNA ladders for bacteriophages $\lambda$ (digested with HindIII) and $\Phi$ X 174 (digested with Hae III). The gels containing total DNA were transferred to nylon membranes (Hybond-N, Amersham), according to Maniatis et al. (1982). The filters were initially hybridized with a mixture of ${ }^{32} \mathrm{P}$ and plasmid clones containing the total mitochondrial genome of Cochliomyia hominivorax (Diptera: Calliphoridae) (Infante-Vargas and Azeredo-Espin, 1995). Subsequently, the filters were hybridized with a mixture of ${ }^{32} \mathrm{P}$ and plasmid clones ( $\mathrm{p} 1 \mathrm{RN} 1$, p1RN2, p2RI, p3RU1 and p3RU2) containing the total mitochondrial genome of Anopheles quadrimaculatus, A species (Cockburn et al., 1990). The hybridizations were performed as described by Maniatis et al. (1982) and the restriction fragments were visualized by autoradiography. Estimates of the haplotype ( $h$; Nei and Tajima, 1981) and nucleotide ( $\pi$; Nei and Miller, 1990) diversities as well as the nucleotide sequence divergence $(\delta$; Nei and Tajima, 1983) among populations were calculated using the computer program REAP (McElroy et al., 1992). Based on the haplotypes, a matrix showing the presence and absence of restriction sites was constructed for cladistic analysis using parsimony criteria (Figure 2).

\section{RESULTS}

The intra- and interpopulational variation in A. nuneztovari mtDNA was determined using 54 individuals from four populations. The five enzymes used yielded six patterns for ClaI and HindIII, four for SstI, three for BclI and two for EcoRI (Table I). EcoRI as well as patterns C of $B c l \mathrm{I}, \mathrm{F}$ of $\mathrm{Cla}$, F of HindIII, and D and E of SstI were not considered in the variability analysis because of technical problems such as partial digestion and background "noise", which made it impossible to determine the haplotype of

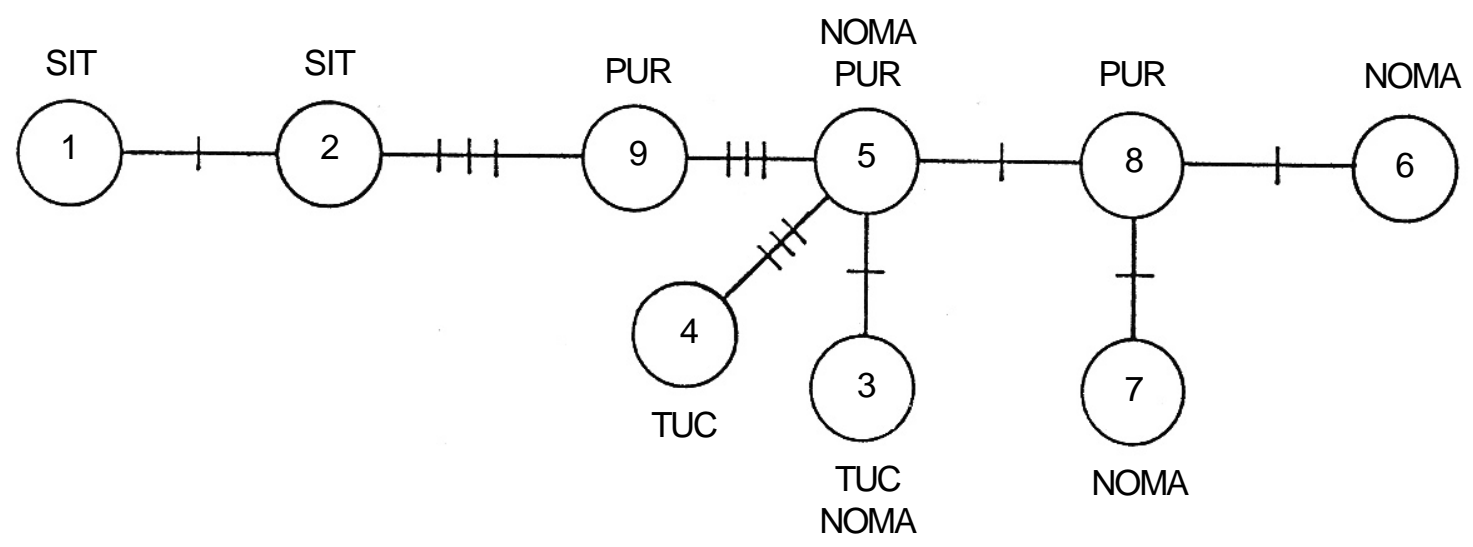

Figure 2 - Cladogram based on the presence/absence of restriction sites in nine haplotypes of Anopheles nuneztovari. For abbreviations, see legend to Table I. 
each individual. The size of A. nuneztovari mtDNA was estimated to be about $15.5 \mathrm{~kb}$. Fragments $<1.0 \mathrm{~kb}$ were rarely observed with the electrophoresis conditions used here (Table I). The mtDNA haplotype of each larvae was derived from the combined restriction patterns of the four enzymes used, which resulted in 23 restriction sites. The sizes of the mtDNA restriction fragments of A. nuneztovari (Table I) have been published for the first time in this study.

The frequencies of the nine haplotypes were determined for the four populations (Table II). Haplotypes 1 and 2, exclusive to SIT, showed similar frequencies and were separated only by a change in the HindIII restriction site. In the Brazilian Amazon, the NOMA population shared haplotypes with the TUC (haplotype 3 ) and PUR (haplotype 5) populations. However, the TUC and PUR populations did not share haplotypes. Haplotype 3 was most frequent in the TUC and NOMA populations whereas haplotype 5 was most frequent in PUR and the second most frequent in NOMA. In the populations from the Brazilian Amazon, haplotypes with lower frequencies occurred within each locality: haplotype 4 at TUC $(\mathrm{N}=3)$, haplotypes 6 and 7 at NOMA ( $\mathrm{N}=2$ each) and haplotypes 8 and 9 at PUR ( $\mathrm{N}=2$ and 1 , respectively).

Haplotype diversity $(h)$ was somewhat high in all populations (Table III). Nucleotide diversity $(\pi)$ varied between 0.0029 and 0.0098 , with the higher values for populations from the Brazilian Amazon. The greater nucleotide diversity presented for the population from TUC is the result of the presence of haplotypes 3 and 4, which differed by four restriction sites. Estimates of nucleotide divergence $(\delta)$ (Table IV) were higher between populations from the Brazilian Amazon and SIT. Haplotypes 1 (ADAA; SIT) and 2 (ADBA; SIT) differed from haplotype 3 (BCCB; NOMA and TUC) by eight and seven restriction sites and from haplotype 5 (BBCB; PUR and NOMA) by seven and six sites, respectively. The divergence among the three populations from the Brazilian Amazon was low, being highest between TUC and PUR. Haplotype 4 (BEDB; TUC) differed from haplotype 5 (BBCB; NOMA, PUR) at three restriction sites and from haplotypes 8 (BBCC; PUR) and 9 (BBBA; PUR) at four restriction sites. The divergence was less between PUR and NOMA (0.0012) than that between NOMA and TUC (0.0015).

The cladogram (Figure 2) was based on parsimony criteria, suggested from a minimum number of mutational events among the nine mtDNA haplotypes. Haplotype 1 was connected to haplotype 2 by one altered restriction site, as was also the case for haplotype pairs 3-5, 5-8, 6-8 and 7-8. Haplotype pairs 2-9, 4-5 and 5-9 were separated by three changes in their restriction sites. Haplotype 4 (TUC) differed from haplotypes 8 (PUR) and 9 (PUR) by four altered restriction sites. Haplotype 9 (PUR) was observed in only one individual and was distinguished by the presence of two rare patterns, B of HindIII and A of SstI. These two patterns, while rare in Brazilian Amazon populations, were frequent in SIT.
Table I - Estimated sizes ( $\mathrm{kb}$ ) for mtDNA restriction fragments in populations of Anopheles nuneztovari.

\begin{tabular}{|lll|}
\hline Enzyme & Restriction fragment $(\mathrm{kb})$ & Population \\
\hline BclI & & \\
A & $9.2,4.3,2.0$ & SIT \\
B & $8.7,4.3,2.0,0.5^{*}$ & TUC, NOMA, PUR \\
C & $9.2,3.4,2.0,0.9^{*}$ & PUR \\
ClaI & & \\
A & $5.9,5.5,3.6,0.4^{*}, 0.3^{*}$ & NOMA, TUC \\
B & $8.9,5.9,0.4^{*}, 0.3^{*}$ & NOMA, PUR, TUC \\
C & $8.9,3.6,2.4,0.4^{*}, 0.3^{*}$ & NOMA, TUC \\
D & $5.9,5.5,3.9,0.4^{*}$ & SIT \\
E & $6.3,5.9,2.9,0.4^{*}$ & TUC \\
F & $8.9,6.3,0.4^{*}, 0.3^{*}$ & PUR \\
EcoRI & & \\
A & $6.4,4.9,4.2$ & PUR, NOMA \\
B & $6.4,4.9,3.2,1.2$ & PUR, SIT, NOMA, TUC \\
HindIII & & \\
A & $4.5,4.2,2.0,1.7,1.0,0.5^{*}$ & SIT \\
B & $8.8,2.0,1.7,1.0,0.5^{*}$ & SIT, PUR \\
C & $8.8,2.7,1.7,1.4,0.6^{*}, 0.5^{*}$ & TUC, NOMA, PUR \\
D & $5.2,3.6,2.7,2.0,1.7,0.5^{*}$ & TUC,PUR \\
E & $11.5,1.7,1.4,0.6^{*}, 0.5^{*}$ & NOMA \\
F & $8.8,1.7,1.4,0.6^{*}, 0.5^{*}$ & PUR \\
SstI & $12.1,3.7$ & \\
A & $6.3,5.7,3.7$ & SIT, PUR \\
B & $9.4,6.3$ & TUC, NOMA, PUR \\
C & 18.9 & PUR, NOMA \\
D & $6.3,5.3,4.1$ & PUR \\
E & PUR \\
\hline
\end{tabular}

SIT $=$ Sitronela $;$ TUC $=$ Tucuruí $;$ NOMA $=$ Nova Mazagão $;$ PUR $=$ Puraquequara. $*=$ Inferred fragments.

Table II - Distribution of mtDNA haplotypes in populations of Anopheles nuneztovari.

\begin{tabular}{|c|c|c|c|c|c|c|}
\hline \multirow[t]{2}{*}{ No. } & \multirow[t]{2}{*}{ Haplotype } & \multicolumn{4}{|c|}{ Population } & \multirow[t]{2}{*}{ Total } \\
\hline & & SIT & TUC & NOMA & PUR & \\
\hline 1 & ADAA & $\begin{array}{c}10 \\
(0.53)\end{array}$ & 0 & 0 & 0 & $\begin{array}{c}10 \\
(0.18)\end{array}$ \\
\hline 2 & ADBA & $\begin{array}{c}9 \\
(0.47)\end{array}$ & 0 & 0 & 0 & $\begin{array}{c}9 \\
(0.17)\end{array}$ \\
\hline 3 & $\mathrm{BCCB}$ & 0 & $\begin{array}{c}6 \\
(0.67)\end{array}$ & $\begin{array}{c}9 \\
(0.52)\end{array}$ & 0 & $\begin{array}{c}15 \\
(0.27)\end{array}$ \\
\hline 4 & BEDB & 0 & $\begin{array}{c}3 \\
(0.33)\end{array}$ & 0 & 0 & $\begin{array}{c}3 \\
(0.06)\end{array}$ \\
\hline 5 & $\mathrm{BBCB}$ & 0 & 0 & $\begin{array}{c}4 \\
(0.24)\end{array}$ & $\begin{array}{c}6 \\
(0.67)\end{array}$ & $\begin{array}{c}10 \\
(0.18)\end{array}$ \\
\hline 6 & BACC & 0 & 0 & $\begin{array}{c}2 \\
(0.12)\end{array}$ & 0 & $\begin{array}{c}2 \\
(0.04)\end{array}$ \\
\hline 7 & BBEC & 0 & 0 & $\begin{array}{c}2 \\
(0.12)\end{array}$ & 0 & $\begin{array}{c}2 \\
(0.04)\end{array}$ \\
\hline 8 & BBCC & 0 & 0 & 0 & $\begin{array}{c}2 \\
(0.22)\end{array}$ & $\begin{array}{c}2 \\
(0.04)\end{array}$ \\
\hline \multirow[t]{2}{*}{9} & BBBA & 0 & 0 & 0 & $\begin{array}{c}1 \\
(0.11)\end{array}$ & $\begin{array}{c}1 \\
(0.02)\end{array}$ \\
\hline & TOTAL & 19 & 9 & 17 & 9 & 54 \\
\hline
\end{tabular}

SIT $=$ Sitronela; TUC $=$ Tucuruí $;$ NOMA = Nova Mazagão; PUR = Puraquequara. Haplotype frequency in parentheses. The haplotypes represent the restriction enzyme pattern derived from Table I, based on order $B c l \mathrm{I}, C l a \mathrm{I}, H i n \mathrm{dIII}$ and SstI. 
Table III - Mean ( \pm SE) haplotype $(h)$ and nucleotide $(\pi)$ diversities in populations of Anopheles nuneztovari.

\begin{tabular}{|lccc|}
\hline Population & $\begin{array}{c}\text { Sample } \\
\text { size }\end{array}$ & $\begin{array}{c}\text { Haplotype } \\
\text { diversity }\end{array}$ & $\begin{array}{c}\text { Nucleotide } \\
\text { diversity }\end{array}$ \\
\hline SIT & 19 & $0.5263(0.0399)$ & 0.0029 \\
TUC & 9 & $0.5000(0.1283)$ & 0.0098 \\
NOMA & 17 & $0.6765(0.0944)$ & 0.0069 \\
PUR & 9 & $0.5556(0.1653)$ & 0.0056 \\
Mean & & $0.5646(0.0015)$ & $0.0063(0.0000)$ \\
\hline
\end{tabular}

SIT $=$ Sitronela $;$ TUC $=$ Tucuruí $;$ NOMA $=$ Nova Mazagão $;$ PUR = Puraquequara.

Table IV - Estimates of nucleotide divergence sequences $(\delta)$ among populations of Anopheles nuneztovari.

\begin{tabular}{|lcccc|}
\hline Population & SIT & TUC & NOMA & PUR \\
\hline SIT & - & & & \\
TUC & 0.0360 & - & & \\
NOMA & 0.0371 & 0.0015 & - & \\
PUR & 0.0329 & 0.0031 & 0.0012 & - \\
\hline
\end{tabular}

SIT $=$ Sitronela $;$ TUC $=$ Tucuruí $;$ NOMA $=$ Nova Mazagão $;$ PUR $=$ Puraquequara.

\section{DISCUSSION}

The size of the mitochondrial genome estimated for A. nuneztovari $(15.5 \mathrm{~kb})$ agrees with previous results obtained for other anophelines (Mitchell et al., 1992; FreitasSibajev et al., 1995). The haplotype and nucleotide diversities found for A. nuneztovari were similar to the values estimated for other species of Neotropical anopheline such as $A$. darlingi $(h=0.693 ; \pi=0.0052)$ and $A$. rangeli ( $h=0.691 ; \pi=0.0085)$ (Conn et al. 1997$)$, and to other A. nuneztovari populations from Brazil $(h=0.539-0.856$; $\pi=0.0062-0.0160)$ (Conn et al., 1998). Compared with other subgenera, our values were higher than those for $A$. (Anopheles) quadrimaculatus, A species $(h=0.370 ; \pi=$ 0.0026) (Perera et al., 1995), but lower than the haplotype diversity of $A$. (Cellia) gambiae $(h=0.907)$ and $A$. (C.) arabiensis $(h=0.828)$ (Besansky et al., 1997). The haplotype diversity in the populations from TUC and PUR was notably lower than that found in the population from NOMA, perhaps because of the small sample size $(\mathrm{N}=9$ each). In the TUC population, the increased nucleotide diversity may reflect either large long-term effective population size or immigration from a previously isolated population (Avise et al., 1987). Mixing of populations may have occurred after the construction of the Tucuruí hydroelectric dam and lake when $2,430 \mathrm{~km}^{2}$ were flooded. In that period, there was a drastic increase of the population of A. nuneztovari, with a subsequent decrease, possibly causing extinctions of some mtDNA lineages while others persisted (Conn et al., 1998), resulting in divergent haplotypes in the same population such as we have observed in TUC. Alternatively, it is possible that intermediate haplotypes were not observed due to undersampling. Although the SIT population sample was larger $(\mathrm{N}=19)$, it showed a smaller nucleotide diversity. This population is located on the edge of this species' limits of distribution, bordered on the west by the Pacific Ocean and on the east by the Andes Mountains. As a result, this population may be more susceptible to events that reduce mtDNA genetic diversity, such as population bottlenecking, founder effects and selective sweeps of favored haplotypes (Harrison, 1991; Sperling and Harrison, 1994). Entomological studies in this area suggest that the density of $A$. nuneztovari is not high, but is sufficient to maintain the transmission of malaria (Fajardo and Alzate, 1987). Interestingly, the SIT population showed an increased mean heterozygosity for allozymes (Scarpassa et al., 1999). Because of the haploid nature and maternal inheritance of the mtDNA, its effective population size is smaller than that of nuclear DNA. Thus, within the population the frequency of an mtDNA haplotype should fluctuate more rapidly than the frequency of a nuclear DNA allele, and therefore should be more sensitive to founder effects and small population size (Roderick, 1996). The low level of nucleotide diversity in the SIT population may be in part attributed to rapid rates of mtDNA lineage extinction.

The nucleotide divergence $(\delta)$ between populations from the Brazilian Amazon and SIT was higher than in the A. quadrimaculatus complex (0.0184-0.0332) (Mitchell et al., 1992). This divergence can be explained by geographical isolation of the populations from SIT, with a reduced or even absent gene flow, that permitted the accumulation of genetic differences. This hypothesis is supported by the presence of haplotypes 1 and 2 , which were considerably different from haplotypes 3 (7-8 changes in the restriction sites) and 5 (6-7 changes in the restriction sites), the two most frequent haplotypes in the Brazilian Amazon populations. In the NOMA population, haplotypes 3 and 5 were the most frequent, which explains the higher mtDNA divergence between this population and that of SIT. Similar to the mtDNA, the genetic distances of allozymes between the Brazilian Amazon and SIT populations (0.1250.148 ) are consistent with those observed among members of anopheline species complexes (Scarpassa et al., 1999). Of the 16 loci analyzed, the locus $\alpha-G p d$ showed a high divergence between SIT and the other populations, including Tibú, northern Colombia (Scarpassa et al., 1999). However, diagnostic loci were not found. Polytene chromosomes of populations from Brazilian Amazon and SIT differ by a fixed inversion in the $\mathrm{X}$ chromosome, inversion frequencies in autosomes and a chromocenter (Conn et al., 1993b). Conn et al. (1998) analyzed mtDNA from 12 populations of $A$. nuneztovari, covering the whole geographic range, and verified that there was a smaller degree of divergence between the Brazilian Amazon and SIT populations (0.0164 to 0.0242). Mitochondrial DNA analysis 
within the C cytotype showed significant differences between SIT and each of Rio Socuavó and El Juval populations (western Venezuela); however, the nucleotide divergence was low (Conn et al., 1998). Of the populations examined by Conn et al. (1998), two (PUR and SIT) were included in our study. The populations NOMA and TUC have been analyzed for the first time in this study. Conn et al. (1998) also studied populations from Boa Vista, Belém and Capanema in the Brazilian Amazon. The distinct values between the two studies may be explained by the greater number of populations analyzed within the Brazilian Amazon by Conn et al. (1998). Sequence data from the ITS2 region showed minimal differences between geographically distant populations, but these differences were sufficient to separate populations from the Brazilian Amazon and SIT into distinct groups (Fritz et al., 1994). However, the morphology of the male genitalia indicates a high similarity between these two populations (Hribar, 1994). Identical male genitalia were also observed between $A$. trinkae and A. dunhami (Peyton, 1993; Lounibos et al., 1998), two species morphologically closely related to $A$. nuneztovari. These findings reinforce the hypothesis that genetic divergence in anopheline mosquitoes is frequently accompanied by little morphological change (Coluzzi, 1988).

Considerable mtDNA divergence has been found in other Neotropical anophelines (reviewed in Conn et al., 1997). Similar to A. nuneztovari, in A. aquasalis the divergence appears to be influenced by ecological factors and a reduction in gene flow, possibly because of geographical barriers such as the Orinoco and Amazon Rivers (Conn et al., 1993a).

The low sequence divergence obtained among the populations of $A$. nuneztovari from the Brazilian Amazon (0.0012-0.0031) suggests genetic homogeneity on a large spatial scale, although the populations from TUC and PUR shared no haplotypes. The low divergence, in contrast to nucleotide diversity, is due mainly to the presence of the two most common haplotypes ( 3 and 5) which are separated by a single restriction site difference. We also think that haplotype 5 may be ancestral, as it is located in the central position of the cladogram (Figure 2) and connected with most of the haplotypes found in the Brazilian Amazon. This result agrees with the allozyme data, where genetic distance observed among populations from the Brazilian Amazon is not higher than that typically found between local populations of a single anopheline species (0.0001-0.0320) (Scarpassa et al., 1999). This genetic similarity also confirms the findings for ITS2 region (Fritz et al., 1994), male genitalia (Hribar, 1994) and egg ultrastructure (Linley et al., 1996). The mtDNA data obtained by Conn et al. (1998) suggested that there are two lineages in the Amazon Basin: 1) eastern Brazilian Amazon (Belém and Capanema) and 2) northern and central Brazilian Amazon including Suriname (Boa Vista, Puraquequara and Victoria) (0.0149-0.0235), a finding which may indicate incipient speciation within the Amazon region. Our data suggest little genetic structure for populations analyzed from the Brazilian Amazon. However, the most divergent haplotypes were observed between TUC (eastern Brazilian Amazon) and PUR (central Brazilian Amazon), but these haplotypes were detected at low frequencies (haplotype 4, TUC; haplotypes 8 and 9, PUR), which may be a consequence of the sample sizes. This hypothesis could be tested by analysis of larger samples for these localities. Alternatively, the two populations (Belém and Capanema) that constitute one of the lineages in the study by Conn et al. (1998) were not analyzed by us, thus explaining the differences between the two studies. Finally, despite the low sequence divergence, our results apparently suggest that gene flow is greater between NOMA and PUR than between TUC and PUR, which agrees partially with the study by Conn et al. (1998).

Our findings suggest two lineages for A. nuneztovari: one in Colombia and the other in the Brazilian Amazon. Considering the population from SIT, the amount of genetic divergence detected by mtDNA and allozyme analyses indicates that this population may eventually be considered an independent evolutionary unit. Further molecular, ecological and morphological analyses of all developmental stages are needed, for a better understanding of the taxonomic status of A. nuneztovari from SIT. The existence of distinct lineages suggested by this and most previous studies may help to explain differences in the malaria transmission patterns involving $A$. nuneztovari from northern South America.

\section{ACKNOWLEDGMENTS}

Research supported by CNPq (No. 480716/93.5) to W.P.T. The authors thank Dr. A.F. Cockburn (University of Florida, USA) for providing the clones of A. quadrimaculatus, A species, and Rosângela A. Rodrigues for technical assistance. The authors also thank M.F. Suarez and H. Hurtado (Universidad del Valle, Cali, Colombia), and G. Alvarez and C. Viveros (Servicio de la Erradicación de Malaria, Buenaventura, Colombia) for providing logistic support in the field in Colombia. Publication supported by FAPESP.

\section{RESUMO}

Neste estudo, apresentamos a variabilidade no DNA mitocondrial de três populações da Amazônia brasileira e uma do oeste da Colômbia (Sitronela) de A. nuneztovari, utilizando-se quatro endonucleases de restrição (BclI, ClaI, HindIII, SstI). A diversidade haplotípica $(h)$ foi ligeiramente elevada em todas as populações $(0.5000$ a 0.6765$)$, enquanto que a diversidade de nucleotídeo $(\pi)$ foi menor na população de Sitronela $(0.0029)$ e maior nas populações da Amazônia brasileira (0.0056 a 0.0098). O grau de divergência de seqüência $(\delta)$ estimado entre as populações da Amazônia brasileira e Sitronela (0.0329 a 0.0371) sugere que estas populações geográficas de A. nuneztovari podem eventualmente representar espécies distintas. Os valores baixos de divergência de sequiência entre as três populações da Amazônia 
brasileira (0.0012 a 0.0031) indicam que estas populações são geneticamente semelhantes. Estes resultados são consistentes com os reportados recentemente para aloenzimas nestas mesmas populações.

\section{REFERENCES}

Arruda, M., Carvalho, M.B., Nussenzweig, R.S., Maracic, M., Pereira, A.W. and Cochrane, H. (1986). Potential vectors of malaria and their different susceptibility to Plasmodium falciparum and Plasmodium vivax in Northern Brazil identified by immunoassay. Am. J. Trop. Med. Hyg. 35: 873-881.

Avise, J.C., Arnold, J., Ball, R.M., Bermingham, E., Lamb, T., Neigel, J.E., Reeb, C.A. and Saunders, N.C. (1987). Intraspecific phylogeography: the mitochondrial DNA bridge between genetics and systematics. Annu. Rev. Ecol. Syst. 18: 489-522.

Besansky, N.J., Lehmann, T., Faley, G.T., Fontenille, D., Braack, L.E.O. Hawley, W.A. and Collins, F.H. (1997). Patterns of mitochondrial variation within and between African malaria vectors, Anopheles gambiae and An. arabiensis, suggest extensive gene flow. Genetics 147: 18171828 .

Cockburn, A.F., Mitchell, S.E. and Seawright, J.A. (1990). Cloning of the mitochondrial genome of Anopheles quadrimaculatus. Arch. Insect Biochem. Physiol. 12: 31-36.

Collins, F.H. and Paskewitz, S.M. (1996). A review of the use of ribosomal DNA (rDNA) to differentiate among cryptic Anopheles species. Insect Mol. Biol. 5: 1-9.

Coluzzi, M. (1988). Anopheline mosquitoes: genetic methods for species differentiation. In: Malaria: Principles and Practice of Malariology (Wernsdorfer, W.H. and McGregor, I., eds.). Churchill Livingstone, Edinburgh, pp. 411-430.

Conn, J. (1990). A genetic study of the malaria vector Anopheles nuneztovari from western Venezuela. J. Am. Mosq. Control Assoc. 6 400-405.

Conn, J., Cockburn, A.F. and Mitchell, S.E. (1993a). Population differentiation of the malaria vector Anopheles aquasalis using mitochondrial DNA. J. Hered. 84: 248-253.

Conn, J., Puertas, Y.R. and Seawright, J.A. (1993b). A new cytotype of Anopheles nuneztovari from western Venezuela and Colombia. J. Am. Mosq. Control Assoc. 9: 294-301.

Conn, J.E., Mitchell, S.E. and Cockburn, A.F. (1997). Mitochondrial DNA variation within and between two species of neotropical anopheline mosquitoes (Diptera: Culicidae). J. Hered. 88: 98-107.

Conn, J.E., Mitchell, S.E. and Cockburn, A.F. (1998). Mitochondrial DNA analysis of the neotropical malaria vector Anopheles nuneztovari Genome 41: 313-327.

Conn, J.E., Freitas-Sibajev, M.G.R., Luz, S.L.B. and Momen, H. (1999). Molecular population genetics of the primary neotropical malaria vector Anopheles darlingi using mtDNA. J. Am. Mosq. Control Assoc. 15: 468-474

Cova-Garcia, P. (1961). Notas Sobre los Anofelinos de Venezuela y su Identificación. 2nd edn. Editoria Grafos, Caracas.

Deane, L.M. (1986). Malaria vectors in Brazil. Mem. Inst. Oswaldo Cruz 81 5-14.

Elliott, R. (1972). The influence of vector behavior on malaria transmissor Am. J. Trop. Med. Hyg. 21: 755-763.

Estrada-Franco, J.G., Lanzaro, G.C., MA, M.C., Walker-Abbey, A., Romans, P., Galvan-Sanchez, C., Cespedes, J.L., Vargas-Sagarnaga, R., Laughinghouse, A., Columbus, I. and Gwadz, R.W. (1993). Characterization of Anopheles pseudopunctipennis sensu latu from three countries of neotropical America from variation in allozymes and ribosomal DNA. Am. J. Trop. Med. Hyg. 49: 735-745.

Fajardo, P. and Alzate, A. (1987). Anopheles nuneztovari como vector de malaria en el Bajo Calima, Buenaventura. Colombia Med. 18: 14-18.

Faran, M.E. (1980). Mosquito studies (Diptera: Culicidae). XXXIV. A revision of the Albimanus section of the subgenus Nyssorhynchus of Anopheles. Contrib. Am. Entomol. Inst. 15: 1-215.

Freitas-Sibajev, M.G.R., Conn, J., Mitchell, S.E., Cockburn, A.F., Seawright, J.A. and Momen, H. (1995). Mitochondrial DNA and morphological analyses of Anopheles darlingi populations from Brazil (Diptera: $\mathrm{Cu}-$ licidae). Mosq. Syst. 27: 78-99.

Fritz, G.N., Conn, J., Cockburn, A.F. and Seawright, J.A. (1994). Sequence analysis of the ribosomal DNA internal transcribed spacer 2 from populations of Anopheles nuneztovari (Diptera: Culicidae). Mol. Biol. Evol. 11: 406-416.

Fritz, G.N., Bermudez, H. and Seawright, J.A. (1995). Genetic differentiation and diagnostic loci of Anopheles nuneztovari, An. trinkae and An. rangeli (Diptera: Culicidae). J. Med. Entomol. 32: 663-672.

Gabaldón, A. (1981). Anopheles nuneztovari: importante vector y agente de malaria refractaria en Venezuela. Bol. Dir. Malariol. Saneam. Amb. $21: 28-38$.

Gorham, J.R., Stojanovich, J.C. and Scott, H.G. (1967). Illustrated Keys to the Anopheline Mosquitoes of Eastern South America. Centers for Disease Control, U.S. Department of Health, Education, and Welfare, Public Health Service, Atlanta, GA.

Harrison, R.G. (1991). Molecular changes at speciation. Annu. Rev. Ecol. Syst. 22: 281-308.

Hribar, L. (1994). Geographic variation of male genitalia of Anopheles nuneztovari (Diptera: Culicidae). Mosq. Syst. 26: 132-144.

Infante-Vargas, M.E.I. and Azeredo-Espin, A.M.L. (1995). Genetic variability in mitochondrial DNA of the screwworm, Cochliomyia hominivorax (Diptera: Calliphoridae), from Brazil. Biochem. Genet. 33: 237-255

Kitzmiller, J.B., Kreutzer, R.D. and Tallaferro, E. (1973). Chromosomal differences in populations of Anopheles nuneztovari. Bull. W. H. Org. 48: 435-455

Lehmann, T., Besansky, N.J., Hawley, W.A., Fahey, T.G. and Kamau, L. (1997). Microgeographic structure of Anopheles gambiae in western Kenya based on mtDNA and microsatellite loci. Mol. Ecol. 6: 243-253.

Linley, J.R., Lounibos, L.P., Conn, J., Duzak, D. and Nishimura, N. (1996). A description and morphometric comparison of eggs from eight geographic populations of the South American malaria vector Anopheles (Nyssorhynchus) nuneztovari (Diptera: Culicidae). J. Am. Mosq. Control Assoc. 12: 275-292

Lounibos, L.P., Wilkerson, R.C., Conn, J.E., Hribar, J., Fritz, G.N. and Danoff-Burg, J.A. (1998). Morphological, molecular, and chromosomal discrimination of cryptic Anopheles (Nyssorhynchus) (Diptera: Culicidae) from South America. J. Med. Entomol. 35: 830-838

Maniatis, T., Fritsh, E.F. and Sambroock, J. (1982). Molecular Cloning: A Laboratory Manual. Cold Spring Harbor Laboratory, Cold Spring Harbor.

McElroy, D., Moran, P., Bermingham, E. and Kornfield, I. (1992). REAP: an integrated environment for the manipulation and phylogenetic analysis of restriction data. J. Hered. 83: 157-158.

Mitchell, S.E., Narang, S.K., Cockburn, A.F., Seawright, J.A. and Goldenthal, M. (1992). Mitochondrial and ribosomal DNA variation among members of the Anopheles quadrimaculatus (Diptera: Culicidae) species complex. Genome 35: 939-950.

Narang, S.K. and Seawright, J.A. (1990). Genetic differentiation among members of species complexes in anopheline mosquitoes (Diptera: Culicidae). In: Eukaryotic Chromosomes: Structural and Functional Aspects (Sobti, R.C. and Obe, G., eds.). Norosa, New Delhi, pp. 59-96.

Narang, S.K., Klein, T.A., Perera, O.P., Lima, J.B. and Tang, A.T. (1993). Genetic evidence for the existence of cryptic species in the Anopheles albitarsis complex in Brazil: allozymes and mitochondrial DNA restriction fragment length polymorphisms. Biochem. Genet. 31:97-111.

Nei, M. and Miller, J.C. (1990). A simple method for estimating average number of nucleotide substitutions within and between populations from restriction data. Genetics 125: 873-879.

Nei, M. and Tajima, F. (1981). DNA polymorphism detectable by restriction endonucleases. Genetics 97: 145-163.

Nei, M. and Tajima, F. (1983). Maximum likelihood estimation of the number of nucleotide substitutions from restriction site data. Genetics 105: 207-217.

Perera, O.P., Mitchell, S.E., Cockburn, A.F. and Seawright, J.A. (1995) Variation in mitochondrial and ribosomal DNA of Anopheles quadrimaculatus species A (Diptera: Culicidae) across a wide geographic range. Ann. Entomol. Soc. Am. 88: 836-845.

Peyton, E.L. (1993). Anopheles (Nyssorhynchus) dunhami, resurrected from synonymy from Anopheles nuneztovari and validated as a senior synonym of Anopheles trinkae (Diptera: Culicidae). Mosq. Syst. 25: 151-156. 
Roderick, G.K. (1996). Geographic structure of insect populations: gene flow, phylogeography, and their uses. Annu. Rev. Entomol. 41: 325-352.

Rubio-Palis, Y. and Curtis, C.F. (1992). Biting and resting behavior of anophelines in Western Venezuela and implications for control of malaria transmission. Med. Veter. Entomol. 6: 325-334.

Scarpassa, V.M., Tadei, W.P. and Suarez, M.F. (1996). Allozyme differentiation among allopatric populations of Anopheles nuneztovari (Diptera: Culicidae). Braz. J. Genet. 19: 265-269.

Scarpassa, V.M., Tadei, W.P. and Suarez, M.F. (1999). Population structure and genetic divergence in Anophele nuneztovari (Diptera: Culicidae) from Brazil and Colombia. Am. J. Trop. Med. Hyg. 60: 1010-1018.

Sperling, F.A.H. and Harrison, R.G. (1994). Mitochondrial DNA variation within and between species of the Papilo machaon group of swallowtail butterflies. Evolution 48: 408- 422.

Steiner, W.W.M., Kitzmiller, J.B. and Osterbur, D.L. (1980). Gene differ- entiation in chromosome races of Anopheles nuneztovari (Gabaldón). Mosq. Syst. 12: 306-319.

Tadei, W.P., Santos, J.M.M., Scarpassa, V.M. and Rodrigues, I.B. (1993). Incidência, distribuição e aspectos ecológicos de espécies de Anopheles (Diptera: Culicidae), em regiões naturais e sob impacto ambiental da Amazônia brasileira. In: Bases Científicas para Estratégias de Preservação e Desenvolvimento da Amazônia (Ferreira, E.J.G., Santos, G.M., Leão, E.L.M. and Oliveira, L.A., eds.). Instituto Nacional de Pesquisas da Amazônia, Manaus, pp. 167-196.

Yasothornsrikul, S., Panyim, S. and Rosenberg, R. (1988). Diagnostic restriction fragment patterns of DNA from the four isomorphic species of Anopheles dirus. Southeast Asian J. Trop. Med. Pub. Health 19: 703-708.

(Received November 16, 1998) 